\title{
Seed Rate and Cultivar Effect on Contribution of Vicia sativa L. Green Manure to Soil Amendment under Mediterranean Conditions
}

\author{
Evangelia Tigka ${ }^{1}$, Dimitrios Beslemes ${ }^{1}$, Ioanna Kakabouki ${ }^{2}\left({ }^{\circ}\right.$, Chrysanthi Pankou $^{1}\left({ }^{1}\right.$, Dimitrios Bilalis $^{2}{ }^{(0)}$, \\ Ioannis Tokatlidis $3, * \mathbb{D}$ and Dimitrios N. Vlachostergios $1, * \mathbb{D}$
}

1 Hellenic Agricultural Organization Demeter, Institute of Industrial and Forage Crops, 1 Theophrastou St., 41335 Larissa, Greece; evitiga@yahoo.gr (E.T.); dbeslemes@gmail.com (D.B.); cpankou@gmail.com (C.P.)

2 Laboratory of Agronomy, Department of Crop Science, Agricultural University of Athens, 11855 Athens, Greece; i.kakabouki@gmail.com (I.K.); bilalisdimitrios@gmail.com (D.B.)

3 Department of Molecular Biology and Genetics, Democritus University of Thrace, 68100 Alexandroupolis, Greece

* Correspondence: itokatl@mbg.duth.gr (I.T.); vlachostergios@gmail.com (D.N.V.)

check for

updates

Citation: Tigka, E.; Beslemes, D.; Kakabouki, I.; Pankou, C.; Bilalis, D.; Tokatlidis, I.; Vlachostergios, D.N.. Seed Rate and Cultivar Effect on Contribution of Vicia sativa L. Green Manure to Soil Amendment under Mediterranean Conditions. Agriculture 2021, 11, 733. https:// doi.org/10.3390/agriculture11080733

Academic Editor: Jochen Mayer

Received: 3 July 2021

Accepted: 29 July 2021

Published: 1 August 2021

Publisher's Note: MDPI stays neutral with regard to jurisdictional claims in published maps and institutional affiliations.

Copyright: (c) 2021 by the authors. Licensee MDPI, Basel, Switzerland. This article is an open access article distributed under the terms and conditions of the Creative Commons Attribution (CC BY) license (https:// creativecommons.org/licenses/by/ $4.0 /)$.
Abstract: The performance of Vicia sativa L. cultivars and cultivar mixtures used as green manure under two seed rates in a Mediterranean environment was investigated in a split plot design, over the period 2014-2016. Six common vetch cultivars grown in pure stands or in mixtures were established at two seed rates $\left(S_{1}=100 \mathrm{Kg} \mathrm{ha}^{-1}\right.$ and $\left.S_{2}=180 \mathrm{~kg} \mathrm{ha}^{-1}\right)$. Growth traits (e.g., plant height, biomass yield, LAI, CGR) were monitored until incorporation into topsoil. The nitrogen (N) concentration of the incorporated biomass along with the decomposition rate were determined, and the effects on the $\mathrm{N}$ supply to the soil were evaluated two, four and six months after biomass incorporation. The increment in residual soil $\mathrm{N}$ four months after green manuring fluctuated from 17 to $45 \mathrm{~kg} \mathrm{ha}^{-1}$ among cultivars, and after six months, from 22 to $50 \mathrm{~kg} \mathrm{ha}^{-1}$. The average decomposition rate of organic substances was slightly higher for $S_{2}$ for all time intervals; however the highest value (62.6\%) was recorded for $S_{1}$ six months after biomass incorporation. Seed rate-independent genotypes were identified with regard to the decomposition of organic matter and are suggested as being suitable for green-manuring farming systems with a low seed rate, a fact that offers options with economic and environmental benefits.

Keywords: Vicia sativa; green manure; seed rate; cultivar; cultivar mixtures; organic matter; $\mathrm{N}$ accumulation; growth parameters

\section{Introduction}

The knowledge of being on the verge of global climate change and the assumption that one of the main driving forces behind these changes is overwhelmingly of anthropogenic origin leads us to the adoption of cultivation strategies that will play a key role in sustainable land use. In this context, the introduction of traditional agricultural practices such as green manuring may represent a viable and robust path to increase productivity and sustainability and preserve the planet's natural resources for future generations to come.

Green manuring is the practice of incorporating undecomposed fresh/dry plant material into soils, either in place or brought from a distance [1,2]. It is widely accepted as a sustainable practice due to crop quality, the yield advantage of the following crops, soil quality improvement, better quality silage, as well as the high utilization efficiency of light, water and nutrients for subsequent crops [3-6]. Green manure approaches may also drive long-term increases in soil organic matter and microbial biomass and the rates of enzyme activity in soil, as well as soil physical properties such as aggregate stability [7] and hydraulic conductivity [8]. Although there are many crops that can be included in green manure-cropping systems, legume crops have an edge over nonlegume crops 
due to their ability to fix atmospheric $N[9,10]$ through a biological process in which atmospheric $\mathrm{N}_{2}$ is converted into a plant-usable form, which potentially could improve soil fertility [11], increase $\mathrm{N}$-uptake efficiency [12], and improve the nitrogen use efficiency of the succeeding crops [13]. Moreover, legumes enhance the availability and conservation of $\mathrm{N}$ for subsequent crops either via the slow release of $\mathrm{N}$ from decomposing green manure residues or through the mineralization of soil $\mathrm{N}$ pools [14]. This has a direct impact on the reduction in the excessive application of synthetic $\mathrm{N}$ fertilizer, which has caused serious environmental damage, including soil deterioration, inefficient fertilizer use, and nitrate contamination of surface and groundwater [15].

Among legume species that could be used as green manure, common vetch (Vicia sativa L.) has great potential, mainly due to its ability to form a vigorous root system that develops nodules even at the early stages, its high tolerance to biotic $[16,17]$ and abiotic stresses [18], its high $\mathrm{N}$ availability [19], and the easiness in its incorporation. Common vetch, originating in the near-Eastern center of diversity [20], is thus a well-adapted crop in the Mediterranean region, western Asia and in countries of the former Soviet Union [21,22]. It is a multi-purpose crop [23,24] with high nutritional value [25], used in pasture, as grain for livestock feed and for the production of silage and hay [26]. Furthermore, it is an excellent candidate for rotations in low-input or organic agriculture systems, as a substantial amount of $\mathrm{N}$ can be left by common vetch crop residues in the soil, available for the subsequent crops $[27,28]$, and due to its high effectiveness in weed control [29,30]. At present, the same cultivars of common vetch that are used for fodder and grain are also used for green manure. However, it is questionable as to whether the selection of a cultivar for use as green manure that is based only on yield traits will be efficient, since other genetic differences between cultivars may allow some of them to accumulate more nitrogen than others [31]. Within this context, the evaluation of different commercial cultivars cultivated for green manure is of great importance. In addition, it would be interesting to investigate the potential of also using common vetch cultivar mixtures that, according to Wolfe [32], vary regarding their ability to produce increased yields, making them better than, worse than or even equal to the mean of the individual cultivar components grown in pure stands. Although previous studies have been conducted on the performance relating to grain yield, mixing ability, stability, dry matter production and protein content of common vetch cultivar mixtures [33,34], there is a lack of information on the ability of such mixtures, composed of suitable cultivars, to satisfy the demands of green manuring systems. Yet, proper assessment of green manure cultivation techniques such as seed rate that affect plant growth rate, the duration of the fully closed canopy, competition for nutrients, water, and light outlines qualified cultivars for use as green manure [31].

Given that in most agricultural soils, the top surface layer loses about $50 \%$ of its antecedent soil organic carbon (SOC) pool in about 25-50 years after conversion from natural ecosystems in temperate climates [35], and that $\mathrm{N}_{2}$-fixation, by grain and forage legumes, contributes only $16 \%-23 \%$ of the global $\mathrm{N}$ supply [36], agricultural ecosystems should adopt sustainable land management such as green manure in order to reduce the need for external $\mathrm{N}$ fertilizer inputs [37] and to contribute to the maintenance of long-term agricultural productivity.

Despite the availability of research data regarding the quantification of $\mathrm{N}$ from green manure practices in subsequent crops [38], little is known about the potential $\mathrm{N}$ increment in the soil, and even less is known about the quantification pattern of organic matter decomposition in the soil from specific superior-performance commercial cultivars of common vetch and their mixtures cultivated as green manure crops at the optimal seed rate. In these ways, green manure approaches may become more profitable and will involve less risk to the farmer, regardless of net value. Therefore, our two-fold objective was to study the effect of (1) seed rate and (2) cultivar/genotype on (a) Vicia sativa L. green manure growth (plant height, LAI, biomass production, CGR and N accumulation ability) and (b) on soil amendment (increase in residual $\mathrm{N}$ and organic matter decomposition) under Mediterranean conditions. 


\section{Materials and Methods}

\subsection{Experimental Site}

The study was carried out at the Institute of Industrial and Forage Crops (IIFC) in Larissa, Central Greece $\left(39^{\circ} 30^{\prime} 02.85^{\prime \prime}\right.$ N, $22^{\circ} 42^{\prime} 50.37^{\prime \prime}$ E, elevation $77 \mathrm{~m}$ ASL), over the period 2014-2016. The soil of the experimental field was classified as typical Vertisol [39,40], while the texture was clay with medium nutrient concentration. The soil particle size distribution (at 0-25 cm sampling depth) of the experimental field is illustrated in Table 1. The study soil had a moderately shallow groundwater table, fluctuating from 200 to $250 \mathrm{~cm}$ below the surface early in the spring, to deeper layers later in the summer.

Table 1. Soil properties of the experimental site.

\begin{tabular}{clcc}
\hline & \multicolumn{4}{l}{ Chemical Properties } & \\
\hline $\mathrm{pH}\left(\mathrm{H}_{2} \mathrm{O} 1: 1\right)\left(25^{\circ} \mathrm{C}\right)$ & 7.4 & $\mathrm{Na}\left(\mathrm{cmol} \mathrm{kg}^{-1}\right)$ & 0.30 \\
Organic Matter $(\%)$ & 0.7 & $\mathrm{~K}\left(\mathrm{cmol} \mathrm{kg}^{-1}\right)$ & 1.5 \\
$\mathrm{P}($ POlsen $)(\mathrm{mg} / \mathrm{kg})$ & 6.2 & $\mathrm{CaCO}_{3}\left(\mathrm{cmol} \mathrm{kg}^{-1}\right)$ & 1.3 \\
EC $(\mathrm{mS} / \mathrm{m})$ & 429 & $\mathrm{mg}\left(\mathrm{NO}_{3}{ }^{-} \mathrm{N}+\mathrm{NO}_{2}{ }^{-} \mathrm{N}\right) / \mathrm{kg}$ soil & 5.8 \\
Total N (Kjeldahl) $(\mathrm{g} / 100 \mathrm{~g})$ & 0.09 & & \\
Sand $(\%)$ & Physical Composition & Clay & 55 \\
Silt $(\%)$ & 20 & Texture & Clay \\
\hline
\end{tabular}

Weather data for the experimental area, such as incident solar radiation, air temperature, rainfall, wind speed, relative humidity and class-A pan evaporation rate, were recorded hourly by the Network of Agro-meteorological Stations Horta srl. In general, the study area (Larissa, Central Greece) is characterized by a typical Mediterranean climate with hot, dry summers and cool, humid winters. Figure 1 illustrates the mean air temperature and precipitation for both experimental years. During the crop cycle period, the mean air temperature reached a maximum value of $13{ }^{\circ} \mathrm{C}$ in 2015 and $15^{\circ} \mathrm{C}$ in 2016 . In the vegetative phase of the crop, from January until April, the total precipitation was $222 \mathrm{~mm}$ in 2015 and $208 \mathrm{~mm}$ in 2016. The total precipitation from May until October was $269 \mathrm{~mm}$ in 2015 and $259 \mathrm{~mm}$ in 2016, a time period crucial for the course of soil amendments such as residual soil $\mathrm{N}$ and the decomposition of organic matter. Hence, weather data showed no considerable differences among the experimental years.

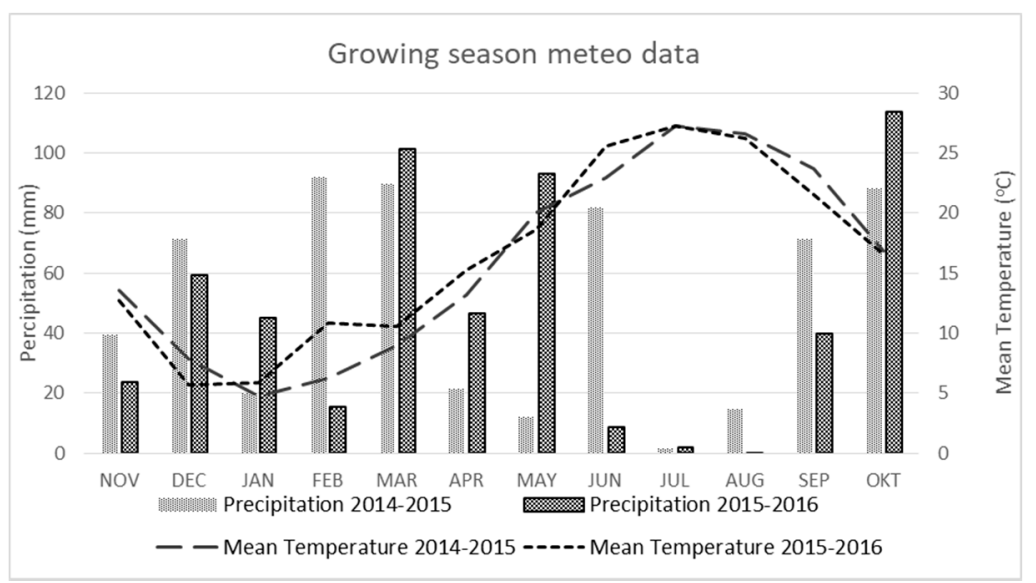

Figure 1. Monthly means of average air temperature $\left({ }^{\circ} \mathrm{C}\right)$ and precipitation $(\mathrm{mm})$ for the 2014-2015 and 2015-2016 growing seasons.

\subsection{Genetic Material}

A total of eight non-GM cultivars of common vetch (Vicia sativa L.), developed by IIFC and registered in the Greek National Variety Catalogue, were selected to be evaluated 
in this study based on (1) productivity and adaptability in Mediterranean region, (2) N fixation profiles, (3) genetic diversity, and (4) cultivation adaptability in a low-input system. Analytically, the genetic material used in field experiments comprised six common vetch cultivars, Alexandros, Kallirroi, Pegasos, Evinos, Zefyros and Tempi, and two cultivar mixtures, Mix1 (Alexandros, Kallirroi, Pegasos) and Mix2 (Kallirroi, Evinos, Zefyros). Genotypic traits such as anthesis in days after sowing (DAS) and weight of 1000 seeds $(1000 \mathrm{SW})$ for all genetic materials, according to breeders' official description, are presented in Table 2. All cultivars and mixtures under study had similar 1000 SW and equally high and uniform seed germination percentage, which led to uniformity in the final established plant density for all the genetic materials in the two specific seed rates applied, approx. 160 and 280 plants $\mathrm{m}^{-2}$ for $\mathrm{S}_{1}$ and $\mathrm{S}_{2}$, respectively. Additionally, the uniformity of the studied material regarding time of anthesis meant that plants were at a similar phenological stage (growth stage/BBCH 65: 50\% flowers open) upon incorporation into topsoil.

Table 2. Days after sowing (DAS) until anthesis and 1000 seed weight for each cultivar and cultivar mixture according to breeders' official description.

\begin{tabular}{ccc}
\hline Varieties & DAS (Until Anthesis) & 1000 SW (g) \\
\hline Alexandros & 139 & 60 \\
Kallirroi & 136 & 64 \\
Pegasos & 135 & 65 \\
Evinos & 132 & 61 \\
Zefyros & 139 & 65 \\
Tempi & 135 & 61 \\
Mix1 & 130 & 63 \\
Mix2 & 132 & 63 \\
\hline
\end{tabular}

\subsection{Field Experiments and Management}

The experimental design was a factorial split plot with three replications. The main factor comprised the two seed rates, $S_{1}=100 \mathrm{~kg} \mathrm{ha}^{-1}$ and $S_{2}=180 \mathrm{~kg} \mathrm{ha}^{-1}$, and the sub-factor comprised the six Greek cultivars and the two cultivar mixtures of Vicia sativa. Each experimental plot occupied an area of $6 \mathrm{~m}^{2}$, with $74 \mathrm{~m}$-long rows that were $0.25 \mathrm{~m}$ apart, and treatments were maintained in the same experimental site with the second-year plot neighboring the first-year plot. The two external rows of every plot were considered as border lines. Non-limiting conditions were maintained throughout the growth cycle by applying $60 \mathrm{~kg} \mathrm{P} \mathrm{ha}^{-1}$ at sowing. For weed control, post sowing, herbicide was applied each year. Sowing occurred during the second half of November in both experimental years.

\subsection{Growth and Productivity}

In each replicate plot, plants were repeatedly sampled from $1 \mathrm{~m}^{2}$ in the two middle rows for the calculation of plant biomass yield, height, specific leaf area (SLA), leaf area index (LAI) and yield components, in order to perform a full growth analysis. Specifically, leaf area index (LAI) was measured using ImageJ Ops software [41]. The samples were taken after the plants had reached the desired height, beginning at 95 DAS, each year, and repeating the procedure every fortnight. All plant samples were cut near the soil surface and the belowground fractions were left in the field. The dry matter of stems and leaves was determined by drying samples in a convection oven at $70{ }^{\circ} \mathrm{C}$ until obtaining constant weights.

\subsection{Determination of Total N Concentrationin Plants, and Soil Samples and Total N Applied}

The final plant samples were taken during the third 10-day interval in April for the first and second year, when 50\% of the plants had reached anthesis, for all cultivars and mixtures that were under study. All 48 samples of aboveground biomass, after drying, were milled to a fine powder with a particle size $<1 \mathrm{~mm}$ to determine the total concentration in plant tissues, using the standard Kjeldahl method [42], in both years of evaluation. Total $\mathrm{N}$ 
applied as green manure was calculated as the product of $\mathrm{N}$ concentration times biomass yield. At the phenological growth stage of anthesis (BBCH 65: 50\% flowers open), all remaining plants in each plot were incorporated into the topsoil. Green manure crops should be incorporated at the flowering stage because with increased crop growth duration, carbonaceous content (carbohydrate and cellulose) increases and nitrogenous content (amino acid and protein) decreases, leading to increase in the $\mathrm{C} / \mathrm{N}$ ratio of crops, which results in slower decomposition of plant material [1]. After a period of two months, soil samples were taken from of each experimental plot in order to determine the impact of green manure in total soil nitrogen in both plant densities. Within each plot, four soil samples were collected at $0-30 \mathrm{~cm}$ depth, sealed in plastic bags and stored in a refrigerator $\left(4^{\circ} \mathrm{C}\right)$ until being processed for further analyses. Soil and sediment samples were air-dried and milled in order to determine the total soil $\mathrm{N}$ in the two months after incorporation (Soil $\mathrm{N}_{1}$ ), again using the standard Kjeldahl method [42]. The same procedure, to determine total soil $\mathrm{N}$, was followed four months $\left(\mathrm{Soil}_{2}\right.$ ) and six months $\left(\mathrm{Soil}_{3}\right)$ after the incorporation of the above ground biomass, on the third 10-day intervals of August and October, respectively, for both experimental years.

\subsection{Decomposition of Organic Matter}

The decomposition of organic matter incorporated into the soil was studied using the mesh bag method [43] in each experimental plot in the field. Identical samples of $5.1 \mathrm{~g}$ of air-dried vetch leaves (without petioles) were weighed and wrapped in polyester bags (mesh $2 \mathrm{~mm} \times 2 \mathrm{~mm}$, size of bags $5 \mathrm{~cm} \times 5 \mathrm{~cm}$ ) and placed in the soil in an upright position, with the upper end $10 \mathrm{~cm}$ below the soil surface with a distance of $2-3 \mathrm{~cm}$ between bags. Three vetch leaf bags were dug up two months later in every experimental plot. The bags were gently washed and air dried at $60{ }^{\circ} \mathrm{C}$ until obtaining constant weights. The mean decrease in dry weight was used to calculate the \% degradation of organic substances. The three mash bags of the second measurement for each plot were dug up four months later, while the three bags of the third measurement were dug up six months after the incorporation of plants into the soil, following the same procedure.

\subsection{Measurements and Calculations}

Crop growth rate (Crop growth rate, CGR, $\mathrm{g} \mathrm{m}^{-2}$ day $^{-1}$ ) was calculated for the period between the stem elongation and anthesis as the difference in biomass accumulation divided by the time in days after sowing [44], and was calculated as the first derivative of Equation (1):

$$
\mathrm{CGR}=\frac{W_{2}-W_{1}}{T_{2}-T_{1}}
$$

$\mathrm{T}_{1}$ and $\mathrm{T}_{2}=$ time in days for stem elongation and anthesis, respectively.

$\mathrm{W}_{1}$ and $\mathrm{W}_{2}=$ dry weight at $\mathrm{T}_{1}$ (stem elongation) and $\mathrm{T}_{2}$ (anthesis), respectively.

Based on the measurements of the leaf area and the dry weight of the green leaves, the specific leaf area (SLA, $\mathrm{m}^{2} \mathrm{~kg}^{-1}$ ) was calculated (data not presented), which represents the total leaf area per unit dry weight of the leaf mass, and through it the leaf area index (LAI, $\mathrm{m}^{2} \mathrm{~m}^{-2}$ ) was calculated [45], by using Equation (2):

$$
L A I=S L * S L A * 10^{-4}
$$

$\mathrm{SL}=$ dry weight of green leaves.

All measured and derived (from the calculations mentioned) data were subjected to analysis of variance (ANOVA) using SPSS22 software (SPSS Inc. version 22.0, IBM Corp, Armonk, NY) following the experimental design. As test criterion for detecting differences between means, the LSD0.05 was used [46], as well as Tukey's honestly significant difference (HSD) test at two levels, with significance $(p=0.05)$ and remarkable significance $(p=0.01)$ [47]. The results regarding residual soil nitrogen and the decomposition of organic matter are graphically represented in a visualization methodology known as PCA 
biplot analysis $[48,49]$. The initial analysis of ANOVA showed the non-significant effect of the factor "Year" as well as the interactions "Year X Seed rate" and "Year X Cultivar". Based on these results, we proceeded with the ANOVA as a two-year average.

\section{Results}

\subsection{Agronomic Traits}

\subsubsection{Plant Height}

Plant heights of eight cultivars grown under two seed rates, as two-year averages, during anthesis are presented analytically in Table 3. Significant differences $(p<0.05)$ for plant height were detected between the two seed rates $\left(S_{1}: 92.12 \mathrm{~cm}\right.$ vs. $\left.S_{2}: 101.21 \mathrm{~cm}\right)$ averaged across genotypes, while significant differences $(p<0.05)$ were also observed among the cultivars and mixtures within each seed rate, suggesting that genotype had a significant effect on plant height. However, when comparing the plant height between seed rates within each cultivar, only the cultivars Evinos and Tempi showed significant differences between $S_{1}$ and $S_{2}$.

Table 3. Agronomic traits at two seed rates $\left(\mathrm{S}_{1}, \mathrm{~S}_{2}\right)$ of each cultivar and cultivar mixture. Plant height ( $\left.\mathrm{cm}\right)$, leaf area index $\left(\mathrm{LAI} ; \mathrm{m}^{2} \mathrm{~m}^{-2}\right.$ ), biomass yield $\left(\mathrm{t} \mathrm{ha}^{-1}\right)$, crop growth rate $\left(\mathrm{CGR} ; \mathrm{t} \mathrm{ha}^{-2} \mathrm{day}^{-1}\right.$ ), plant nitrogen concentration (N\%) and total $\mathrm{N}$ applied. Different letters indicate significant differences between/among means of cultivars within the same seed rate at $p<0.05$, according to Tukey's method, and LSD+ indicate significant differences between seed rates within the same cultivar.

\begin{tabular}{|c|c|c|c|c|c|c|c|c|c|c|}
\hline & \multicolumn{10}{|c|}{ Cultivar } \\
\hline & Seed Rate & Alexandros & Kallirroi & Pegasos & Evinos & Zefyros & Tempi & $\operatorname{Mix}_{1}$ & $\operatorname{Mix}_{2}$ & Mean \\
\hline \multirow{3}{*}{$\begin{array}{c}\text { Plant } \\
\text { Height }(\mathrm{cm})\end{array}$} & $S_{1}$ & $103.2^{\mathrm{c}}$ & $88.3^{a, b}$ & $91.3^{\mathrm{b}}$ & $92.2^{\mathrm{b}}$ & $83.6^{a, b}$ & $80.6^{\mathrm{a}}$ & $88.2^{\mathrm{a}, \mathrm{b}}$ & $110.3^{c}$ & $92.12^{\mathrm{A}}$ \\
\hline & $\mathrm{S}_{2}$ & $110.6^{\mathrm{b}}$ & $99.7^{a, b}$ & $96.6^{a, b}$ & $99.7^{\mathrm{a}, \mathrm{b}}$ & $90.7^{\mathrm{a}}$ & $93.9^{a, b}$ & $99.9^{a, b}$ & $116.9^{b}$ & $101.21^{\mathrm{B}}$ \\
\hline & $\mathrm{LSD}^{+}$ & ns & ns & ns & $7.5 *$ & ns & $13.3 *$ & ns & ns & \\
\hline \multirow{3}{*}{$\mathrm{LAI}\left(\mathrm{m}^{2} \mathrm{~m}^{-2}\right)$} & $\mathrm{S}_{1}$ & $5.4^{\mathrm{c}}$ & $5.1^{\mathrm{b}, \mathrm{c}}$ & $3.7^{\mathrm{a}, \mathrm{b}}$ & $3.5^{\mathrm{a}}$ & $4.1^{\mathrm{a}, \mathrm{b}, \mathrm{c}}$ & $3.0^{\mathrm{a}}$ & $4.1^{\mathrm{a}, \mathrm{b}, \mathrm{c}}$ & $5.9^{d}$ & $4.36^{\mathrm{A}}$ \\
\hline & $\mathrm{S}_{2}$ & $6.5^{\mathrm{a}}$ & $5.4^{\mathrm{a}}$ & $6.0^{\mathrm{a}}$ & $5.9^{\mathrm{a}}$ & $5.7^{\mathrm{a}}$ & $5.5^{\mathrm{a}}$ & $6.1^{\mathrm{a}}$ & $6.4^{\mathrm{a}}$ & $5.91^{\mathrm{B}}$ \\
\hline & $\mathrm{LSD}^{+}$ & ns & ns & $2.3 *$ & $2.4 *$ & ns & ns & $2.5 *$ & ns & \\
\hline \multirow{3}{*}{$\begin{array}{l}\text { Biomass yield } \\
\quad\left(\mathrm{t} \mathrm{ha}^{-1}\right)\end{array}$} & $\mathrm{S}_{1}$ & $4.47^{\mathrm{b}}$ & $4.06^{\mathrm{b}}$ & $3.64^{a, b}$ & $3.97^{\mathrm{a}, \mathrm{b}}$ & $4.51^{\mathrm{b}}$ & $2.19^{a}$ & $4.22^{\mathrm{b}}$ & $4.37^{\mathrm{b}}$ & $3.93^{\mathrm{A}}$ \\
\hline & $\mathrm{S}_{2}$ & $7.79^{\mathrm{c}}$ & $7.00^{\mathrm{a}, \mathrm{b}}$ & $6.79^{a}$ & $7.33^{\mathrm{b}}$ & $7.38^{b, c}$ & $6.84^{a, b}$ & $7.48^{\mathrm{b}, \mathrm{c}}$ & $7.49^{\mathrm{b}, \mathrm{c}}$ & $7.33^{\mathrm{B}}$ \\
\hline & $\mathrm{LSD}^{+}$ & $3.32 *$ & $2.94^{* *}$ & $3.15 *$ & $3.36^{* *}$ & $2.87^{*}$ & $4.65^{* *}$ & $3.26 * *$ & $3.12 * *$ & \\
\hline \multirow{3}{*}{$\begin{array}{c}\text { CGR } \\
\left(\mathrm{t} \mathrm{ha}^{-2} \mathrm{day}^{-1}\right)\end{array}$} & $\mathrm{S}_{1}$ & $0.137^{\mathrm{b}}$ & $0.143^{\mathrm{b}, \mathrm{c}}$ & $0.141^{b}$ & $0.155^{\mathrm{d}}$ & $0.201^{f}$ & $0.116^{\mathrm{a}}$ & $0.176^{\mathrm{e}}$ & $0.148^{\mathrm{c}, \mathrm{d}}$ & $0.152^{\mathrm{A}}$ \\
\hline & $\mathrm{S}_{2}$ & $0.357^{\mathrm{d}}$ & $0.228^{\mathrm{a}}$ & $0.295^{b}$ & $0.358^{d}$ & $0.312^{c}$ & $0.285^{\mathrm{b}}$ & $0.319^{c}$ & $0.309^{c}$ & $0.308^{B}$ \\
\hline & $\mathrm{LSD}^{+}$ & $0.22 * *$ & $0.08 * *$ & $0.15^{* *}$ & $0.2^{* *}$ & 0.11 * & $0,18^{* *}$ & $0.14^{* *}$ & $0.16^{* *}$ & \\
\hline \multirow{3}{*}{ Plant N\% } & $\mathrm{S}_{1}$ & $2.95^{\mathrm{a}}$ & $3.13^{a, b}$ & $3.61^{b, c}$ & $3.19^{a, b}$ & $2.91^{\mathrm{a}}$ & $3.19^{a, b}$ & $3.98^{\mathrm{C}}$ & $3.18^{a, b}$ & $20.89^{A}$ \\
\hline & $\mathrm{S}_{2}$ & $3.03^{a}$ & $3.41^{\mathrm{a}}$ & $3.49^{a, b}$ & $3.29^{a, b}$ & $2.94^{\mathrm{a}}$ & $3.2^{\mathrm{a}}$ & $4.1^{b}$ & $3.2^{\mathrm{a}}$ & $20.82^{\mathrm{A}}$ \\
\hline & $\mathrm{LSD}^{\dagger}$ & ns & ns & ns & ns & ns & ns & ns & ns & \\
\hline \multirow{3}{*}{$\begin{array}{l}\text { Total } N \text { applied } \\
\qquad\left(\mathrm{t} \mathrm{ha}^{-1}\right)\end{array}$} & $\mathrm{S}_{1}$ & $13.2^{\mathrm{b}, \mathrm{c}}$ & $12.7^{\mathrm{b}}$ & $13.1^{\mathrm{b}}$ & $12.6^{\mathrm{b}}$ & $13.1^{b}$ & $7^{\mathrm{a}}$ & $16.8^{\mathrm{d}}$ & $13.9^{\mathrm{c}}$ & $12.81^{\mathrm{A}}$ \\
\hline & $\mathrm{S}_{2}$ & $23.6^{\mathrm{a}}$ & $23.8^{\mathrm{a}}$ & $23.7^{\mathrm{a}}$ & $24.1^{\mathrm{a}}$ & $21.7^{\mathrm{a}}$ & $21.9^{\mathrm{a}}$ & $30.7^{\mathrm{b}}$ & $24^{\mathrm{a}}$ & $24.19^{B}$ \\
\hline & $\mathrm{LSD}^{+}$ & $10.4^{* *}$ & $11.1^{* *}$ & $10.6^{* *}$ & $11.5^{* *}$ & $8.6^{*}$ & $14.9^{* *}$ & $13.9^{* *}$ & $10.1^{* *}$ & \\
\hline
\end{tabular}

$\mathrm{S}_{1}, 100 \mathrm{~kg} \mathrm{ha}^{-1} ; \mathrm{S}_{2}, 180 \mathrm{~kg} \mathrm{ha}^{-1} ; \mathrm{LSD}^{\dagger}$, least significant deference at $p<0.05$ and $p<0.01 ;{ }^{* * *}$ significant at $p<0.05$ and $p<0.01$, respectively; ns, no significant $(p>0.05)$.

The variation rate of the plant height of all cultivars is illustrated in Figure 1. Analytically, plants from all cultivars and cultivar mixtures, after an initial period of crop establishment, at approximately 68 DAS (about 68 days), reached a height of about $20 \mathrm{~cm}$. Then, plant height increased almost linearly until flowering (50\% of plant in anthesis), reaching higher values, while the stem elongation ceased due to transition to the reproducing stage. This vegetative phase is the most appropriate at which to incorporate the plants into the topsoil, because the stem is still thin without becoming woody, meaning lower lignin concentrations [50].

It is worth noting (Figure 2) that plant heights were increased almost parallel to each other, meaning that the differences in values remained almost identical in all cases. The mixture Mix2 recorded higher rates of plant height increase, reaching a mean of 4.5 and $5 \mathrm{~cm} \mathrm{~d}^{-1}$ for the $S_{1}$ and $S_{2}$ seed rates, respectively, while the cultivar Alexandros had a 
mean rate increase of $4.4 \mathrm{~cm} \mathrm{~d}^{-1}$ for both seed rates. Likewise, those two cultivars recorded greater final height, i.e., 103.2 and $110.6 \mathrm{~cm}$ for cv. Alexandros, and 110.3 and $116.9 \mathrm{~cm}$ for mixture Mix2, at $S_{1}$ and $S_{2}$, respectively, and their values were different $(p<0.05)$ from all the other recorded values at the two seed rates.

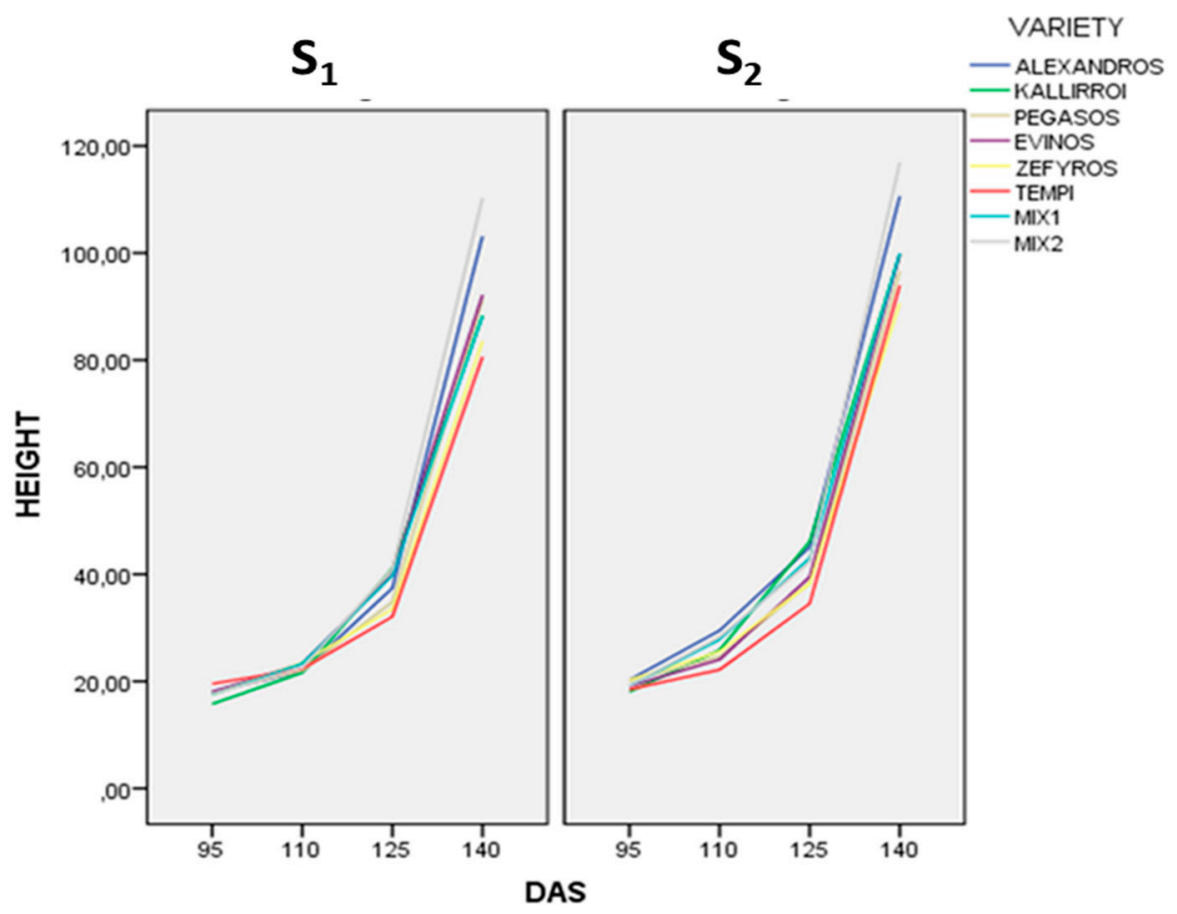

Figure 2. Variation rate of plant height $(\mathrm{cm})$ of six cultivars and two mixture cultivars of common vetch in two seed rates $\left(S_{1}: 100 \mathrm{~kg} \mathrm{ha}^{-1} ; S_{2}: 180 \mathrm{~kg} \mathrm{ha}^{-1}\right.$, as a two-year average. DAS indicate days after sowing.

\subsubsection{Leaf Area Index}

LAI values, as two-year averages, during anthesis are presented in Table 3, while the LAI variation rate between cultivars for the two seed rates is illustrated in Figure 3. Significant differences $(p<0.05)$ were detected between the two seed rates $\left(S_{1}: 4.36\right.$ vs. $S_{2}$ : $5.91)$ averaged across cultivars, whereas significant differences $(p<0.05)$ among the studied genotypes were found in the low seed rate $\left(S_{1}\right)$ in contrast to the high seed rate $\left(S_{2}\right)$, where no significant differences among cultivars were detected. In addition, the leaf area index for the majority of cultivars, except for Pegasos, Evinos and Mix1, was not affected by seed rate $(p<0.05)$. No significant interactions $(p<0.05)$ were observed between the measured or calculated variables (data not shown).

Specifically, Figure 3 shows that LAI of all studied cultivars and mixtures increased initially at small rates, reaching values bigger than 1.0 at the beginning of spring and remained at small values for almost a month. Then, LAI increased at remarkable high rates, reaching values above 3.0 in almost all cases, and stayed high until flowering.

It is noteworthy that at the $S_{1}$ seed rate, LAI started decreasing by the start of anthesis, apparently due to the ageing and falling off of the older leaves, a phenomenon which we did not observe at the $S_{2}$ seed rate, except for cultivar Kallirroi, in which the older leaves start falling immediately after anthesis. Concurrently, all cultivars that were cultivated at the $S_{2}$ seed rate produced higher LAI values compared to those that were cultivated at the $S_{1}$ seed rate. In fact, at $S_{2}$, LAImax reached 6.5 and 6.4 for cv. Alexandros and Mix2, respectively, whereas at $S_{1}$, the corresponding numbers were 5.4 and 5.9 (Table 3). 


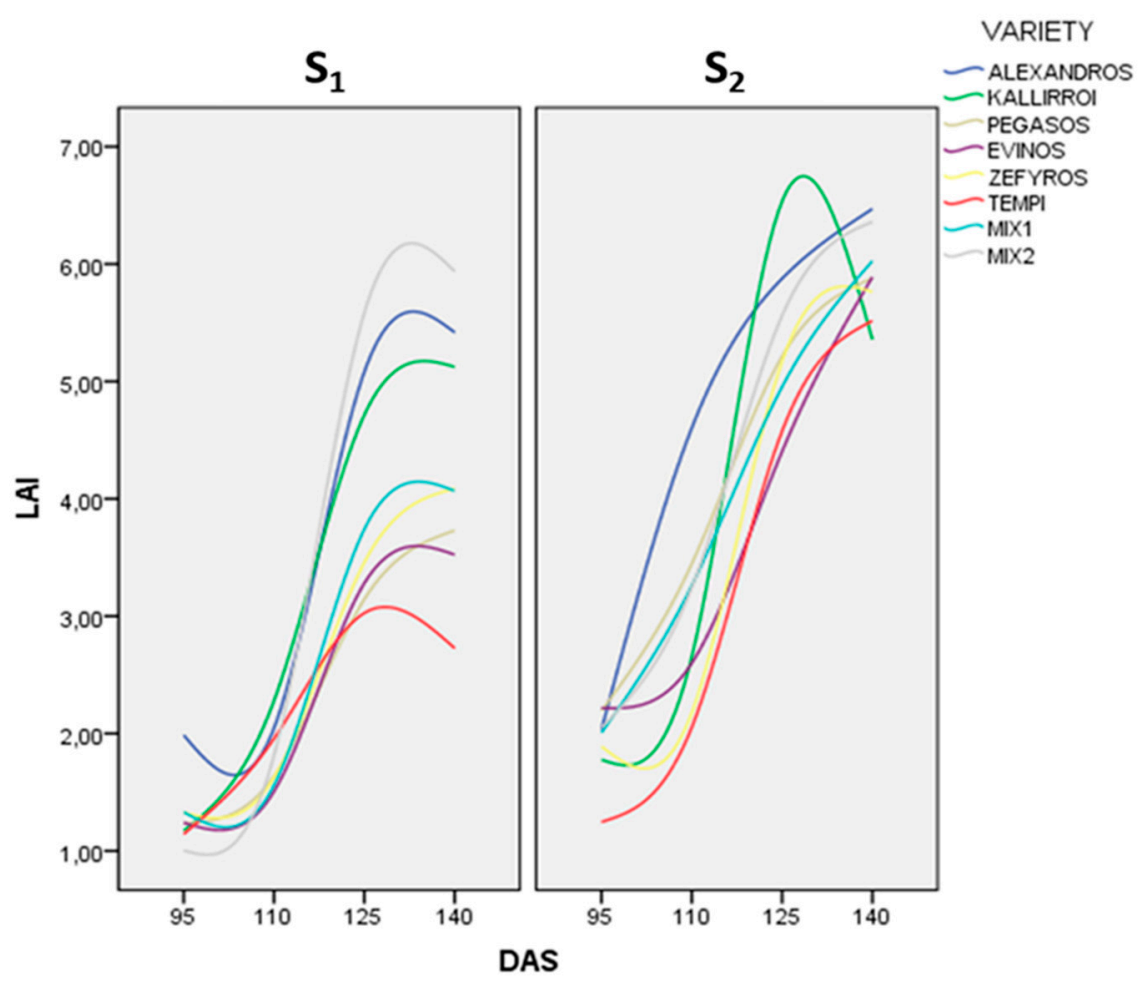

Figure 3. Variation rate of the leaf area index $\left(\mathrm{LAI} ; \mathrm{m}^{2} \mathrm{~m}^{-2}\right)$ of six cultivars and two cultivar mixtures of common vetch in two seed rates $\left(\mathrm{S}_{1}: 100 \mathrm{~kg} \mathrm{ha}^{-1} ; \mathrm{S}_{2}: 180 \mathrm{~kg} \mathrm{ha}^{-1}\right)$, as a two-year average. DAS indicates days after sowing.

\subsubsection{Biomass Yieldand CGR}

The means of biomass yield and crop growth rate are presented in Table 3, as two-year averages for every studied cultivar and mixtures. Significant differences $(p<0.05$ and $p<0.01$ ) in biomass productivity and in CGR were found between seed rates averaged across cultivars $\left(S_{1}: 3.93\right.$ tha ${ }^{-1}$ vs. $S_{2}: 7.33$ t.ha $^{-1}$ for biomass and $S_{1}: 0.152$ tha ${ }^{-1}$ vs. $\mathrm{S}_{2}: 0.308 \mathrm{t}^{\mathrm{h} \mathrm{h}^{-1}}$ for CGR) and within each genotype for all cultivars and mixtures tested, almost throughout the growing period and specifically during flowering ( $50 \%$ of plants in anthesis). Significant differences ( $p<0.05$ and $p<0.01$ ) in biomass production and CGR were also detected between cultivars grown at each seed rate.

Analytically, dry biomass production fluctuated from 2.19 to 4.51 tha ${ }^{-1}$ for $\mathrm{S}_{1}$, while for $S_{2}$ it fluctuated from 6.79 to 7.79 tha $^{-1}$. Alexandros exhibited higher biomass production for both seed rates. The cultivar Tempi recorded a remarkable biomass increase in response to seed rate, reaching values of 4.65 tha $^{-1}$. The accumulation of dry matter per square meter, from stem elongation until flowering, increased as a function of seed rate and in almost all cultivars under study recorded double values for $S_{2}$. Specifically, for $S_{1}$, a higher growth rate was recorded from the cultivar Zefyros $\left(0.201 \mathrm{t} \mathrm{ha}^{-2}\right.$ day $\left.^{-1}\right)$ and the mixture Mix1 $\left(0.176 \mathrm{t} \mathrm{ha}^{-2} \mathrm{day}^{-1}\right)$, while for $\mathrm{S}_{2}$, a higher growth rate was recorded from the cultivars Alexandros and Evinos $\left(0.36 \mathrm{tha}^{-2}\right.$ day $^{-1}$ day $\left.^{-1}\right)$.

\subsubsection{Plant Nitrogen Concentration and Total Nitrogen Applied}

Plant tissue total $\mathrm{N}$ concentration demonstrated statistical differences among cultivars grown at each seed rate. Contrarily, no differences $(p<0.05)$ were detected between seed rates averaged across cultivars, as well as within each cultivar (Table 3). Specifically, Mix1 statistically differed from the other cultivars and mixtures, reaching the highest values estimated at $3.98 \%$ and $4.1 \%$ for the $\mathrm{S}_{1}$ and $\mathrm{S}_{2}$ seed rates, respectively. The lowest values were observed in cv. Zefyros and were calculated as $2.91 \%$ and $2.94 \%$ for the $S_{1}$ and $S_{2}$ seed rates, respectively. Additionally, significant differences were detected $(p<0.05$ and $p<0.01)$ in the total nitrogen applied between seed rates averaged across cultivars $\left(\mathrm{S}_{1}\right.$ : 
12.81 tha $^{-1}$ vs. $\mathrm{S}_{2}: 24.19$ tha $^{-1}$ ) and among cultivars grown at the same seed rate (Table 3). Once again, cultivar mixture Mix1 statistically differed from the other cultivars, at both seed rates, recording higher values (viz. 16.8 tha $^{-1}$ at $S_{1}$ and 30.7 tha ${ }^{-1}$ at $S_{2}$ ), while cv Tempi recorded the lowest value of total nitrogen applied (viz. 7 tha $^{-1}$ ) at the low seed rate.

\subsection{Soil Amendment}

\subsubsection{Residual Soil Nitrogen $(\mathrm{N})$}

Residual soil nitrogen $(\mathrm{N})$ estimated from soil analysis by the standard Kjeldahl method at two (Soil $\mathrm{N}_{1}$ ), four (Soil $\mathrm{N}_{2}$ ) and six $\left(\mathrm{Soil} \mathrm{N}_{3}\right.$ ) months after plants were incorporated into the soil as green manure is presented in Table 4 . It is worth mentioning that the initial soil nitrogen of the experimental field was calculated, using the same method, at $87 \mathrm{~kg} \mathrm{ha}^{-1}$. Cultivar clusters regarding the residual soil nitrogen contribution are illustrated in Figure 4.

Table 4. Soil nitrogen and soil organic matter at two, four and six months after the incorporation of Vicia sativa plants at two seed rates $\left(\mathrm{S}_{1}, \mathrm{~S}_{2}\right)$ for each cultivar and cultivar mixture. Different letters indicate significant differences between/among means of cultivars grown at the same seed rate at $p<0.05$, according to Tukey's method, and LSD+ indicates significant differences between seed rates within the same cultivar.

\begin{tabular}{|c|c|c|c|c|c|c|c|c|c|c|}
\hline & \multicolumn{10}{|c|}{ Cultivar } \\
\hline & Seed Rate & Alexandros & Kallirroi & Pegasos & Evinos & Zefyros & Tempi & $\mathbf{M i x}_{1}$ & $\operatorname{Mix}_{2}$ & Mean \\
\hline \multirow{3}{*}{$\begin{array}{c}\text { Soil N } \\
\left(\mathrm{kg} \mathrm{ha}^{-1}\right)\end{array}$} & $\mathrm{S}_{1}$ & $99^{a}$ & $103^{a}$ & $100^{\mathrm{a}}$ & $104^{\mathrm{a}}$ & $93^{\mathrm{a}}$ & $104^{\mathrm{a}}$ & $106^{\mathrm{a}}$ & $102^{\mathrm{a}}$ & $101^{\mathrm{A}}$ \\
\hline & $\mathrm{S}_{2}$ & $95^{\mathrm{a}}$ & $96^{\mathrm{a}, \mathrm{b}}$ & $97^{a, b}$ & $107^{b, c}$ & $105^{a, b, c}$ & $99^{a, b, c}$ & $108^{\mathrm{c}}$ & $101^{a, b, c}$ & $101^{\mathrm{A}}$ \\
\hline & $\mathrm{LSD}^{+}$ & ns & ns & ns & ns & ns & ns & ns & ns & \\
\hline \multirow{3}{*}{ Soil $\mathrm{N}_{2}\left(\mathrm{~kg} \mathrm{ha}^{-1}\right)$} & $\mathrm{S}_{1}$ & $107^{a, b}$ & $115^{\mathrm{a}, \mathrm{b}}$ & $113^{a, b}$ & $106^{a, b}$ & $101^{\mathrm{a}}$ & $114^{\mathrm{a}, \mathrm{b}}$ & $126^{\mathrm{b}}$ & $110^{\mathrm{a}, \mathrm{b}}$ & $112^{\mathrm{A}}$ \\
\hline & $\mathrm{S}_{2}$ & $109^{a}$ & $125^{a, b}$ & $116^{\mathrm{a}, \mathrm{b}}$ & $124^{\mathrm{a}, \mathrm{b}}$ & $132^{\mathrm{b}}$ & $123^{a, b}$ & $130^{\mathrm{b}}$ & $122^{a, b}$ & $122^{\mathrm{A}}$ \\
\hline & $\mathrm{LSD}^{+}$ & ns & ns & ns & ns & $31 *$ & ns & ns & $\mathrm{ns}$ & \\
\hline \multirow{3}{*}{ Soil $\mathrm{N}_{3}\left(\mathrm{~kg} \mathrm{ha}^{-1}\right)$} & $\mathrm{S}_{1}$ & $115 b^{c}$ & $118^{\mathrm{d}, \mathrm{e}}$ & $123^{e, f}$ & $124^{\mathrm{f}}$ & $109^{a}$ & $114^{\mathrm{b}, \mathrm{c}}$ & $130 \mathrm{~g}$ & $113^{\mathrm{a}, \mathrm{b}}$ & $118^{\mathrm{A}}$ \\
\hline & $\mathrm{S}_{2}$ & $125 b^{c}$ & $133^{e, f}$ & $115^{\mathrm{a}}$ & $122^{b}$ & $137^{\mathrm{f}}$ & $129^{\mathrm{c}, \mathrm{e}}$ & $136^{\mathrm{f}}$ & $122^{\mathrm{b}}$ & $127^{\mathrm{B}}$ \\
\hline & $\mathrm{LSD}^{+}$ & $10 *$ & 15 * & $8^{*}$ & $2 * *$ & $29 * *$ & $15^{* *}$ & $6^{*}$ & $9^{* *}$ & \\
\hline \multirow{3}{*}{$\mathrm{ORG}_{1}(\%)$} & $\mathrm{S}_{1}$ & $34.9^{\mathrm{a}, \mathrm{b}}$ & $34.4^{\mathrm{a}, \mathrm{b}}$ & $25.1^{\mathrm{a}}$ & $30.5^{a, b}$ & $38.9^{\mathrm{a}, \mathrm{b}}$ & $42.8^{\mathrm{b}}$ & $32.4^{\mathrm{a}, \mathrm{b}}$ & $27.6^{a, b}$ & $33^{A}$ \\
\hline & $\mathrm{S}_{2}$ & $42^{\mathrm{b}}$ & $34.2^{\mathrm{a}}$ & $28.48^{a}$ & $29.3 \mathrm{a}$ & $35^{a, b}$ & $33.8^{\mathrm{a}}$ & $38.4^{\mathrm{a}, \mathrm{b}}$ & $34.7^{a, b}$ & $35^{\mathrm{B}}$ \\
\hline & $\mathrm{LSD}^{+}$ & $7.1 *$ & ns & ns & ns & ns & $9 *$ & $6^{*}$ & $7.1 *$ & \\
\hline \multirow{2}{*}{$\mathrm{ORG}_{2}(\%)$} & $S_{1}$ & $42.1^{\mathrm{a}}$ & $49.5^{\mathrm{a}, \mathrm{b}}$ & $43^{a}$ & $44^{\mathrm{a}, \mathrm{b}}$ & $45.9^{\mathrm{a}, \mathrm{b}}$ & $57.3^{\mathrm{b}}$ & $40^{\mathrm{a}, \mathrm{b}}$ & $42.3^{\mathrm{a}}$ & $45.5^{\mathrm{A}}$ \\
\hline & $\mathrm{S}_{2}$ & $50.8 b^{c}$ & $46.5^{\mathrm{a}, \mathrm{b}, \mathrm{c}}$ & $41.7^{\mathrm{a}}$ & $47.1^{\mathrm{a}, \mathrm{b}, \mathrm{c}}$ & $52.2^{\mathrm{C}}$ & $49.3^{b, c}$ & $49.1^{b, c}$ & $54^{\mathrm{c}}$ & $48.8^{\mathrm{B}}$ \\
\hline \multirow{4}{*}{$\mathrm{ORG}_{3}(\%)$} & $\mathrm{LSD}^{\dagger}$ & $8.7^{*}$ & ns & ns & ns & ns & $8^{*}$ & 9.1 * & 11.7 * & \\
\hline & $\mathrm{S}_{1}$ & $47.1^{\mathrm{a}}$ & $48^{a, b}$ & $45.6^{\mathrm{a}}$ & $42.2^{\mathrm{a}}$ & $46.7^{\mathrm{a}}$ & $62.6^{\mathrm{b}}$ & $37.3^{\mathrm{a}}$ & $45^{\mathrm{a}}$ & $46.8^{\mathrm{A}}$ \\
\hline & $\mathrm{S}_{2}$ & $49.9^{b, c}$ & $47.6^{\mathrm{b}}$ & $40.41^{\mathrm{a}}$ & $46.8^{\mathrm{a}, \mathrm{b}}$ & $46.6^{\mathrm{a}, \mathrm{b}}$ & $56.1^{\mathrm{c}}$ & $46.7^{\mathrm{a}, \mathrm{b}}$ & $52.3^{b, c}$ & $48.3^{\mathrm{B}}$ \\
\hline & $\mathrm{LSD}^{+}$ & ns & ns & ns & ns & ns & ns & $9.4^{* *}$ & $7.3 *$ & \\
\hline
\end{tabular}

$\mathrm{N}_{1}, \mathrm{~N}_{2}, \mathrm{~N}_{3}\left(\mathrm{~kg} \mathrm{ha}^{-1}\right)$ : soil nitrogen two, four, six months after biomass incorporation, respectively. ORG. MATTER ${ }_{1,2,3}(\%)$ : soil organic matter two, four, six months after biomass incorporation, respectively. LSD ${ }^{\dagger}$, least significant difference at $p<0.05$ and $p<0.01$. *** significant at $p<0.05$ and $p<0.01$, respectively; ns, not significant $(p>0.05)$.

In the two-month period after the incorporation of common vetch plants, it was observed that there was an increment in residual soil nitrogen, and higher values were recorded in relation to the initial value in all cases under study. Significant differences among cultivars were detected only at the $S_{2}$ seed rate. Contrarily, no significant differences were recorded between seed rates, either averaged across cultivars or within each cultivar. The highest values were calculated at 106 and $108 \mathrm{~kg} \mathrm{ha}^{-1}$ for $S_{1}$ and $S_{2}$, respectively, for the mixture Mix1. The lowest value was estimated at $93 \mathrm{~kg} \mathrm{ha}^{-1}$ for $\mathrm{cv}$. Zefyros at $\mathrm{S}_{1}$ and $95 \mathrm{~kg} \mathrm{ha}^{-1}$ for cv. Alexandros at $S_{2}$. 


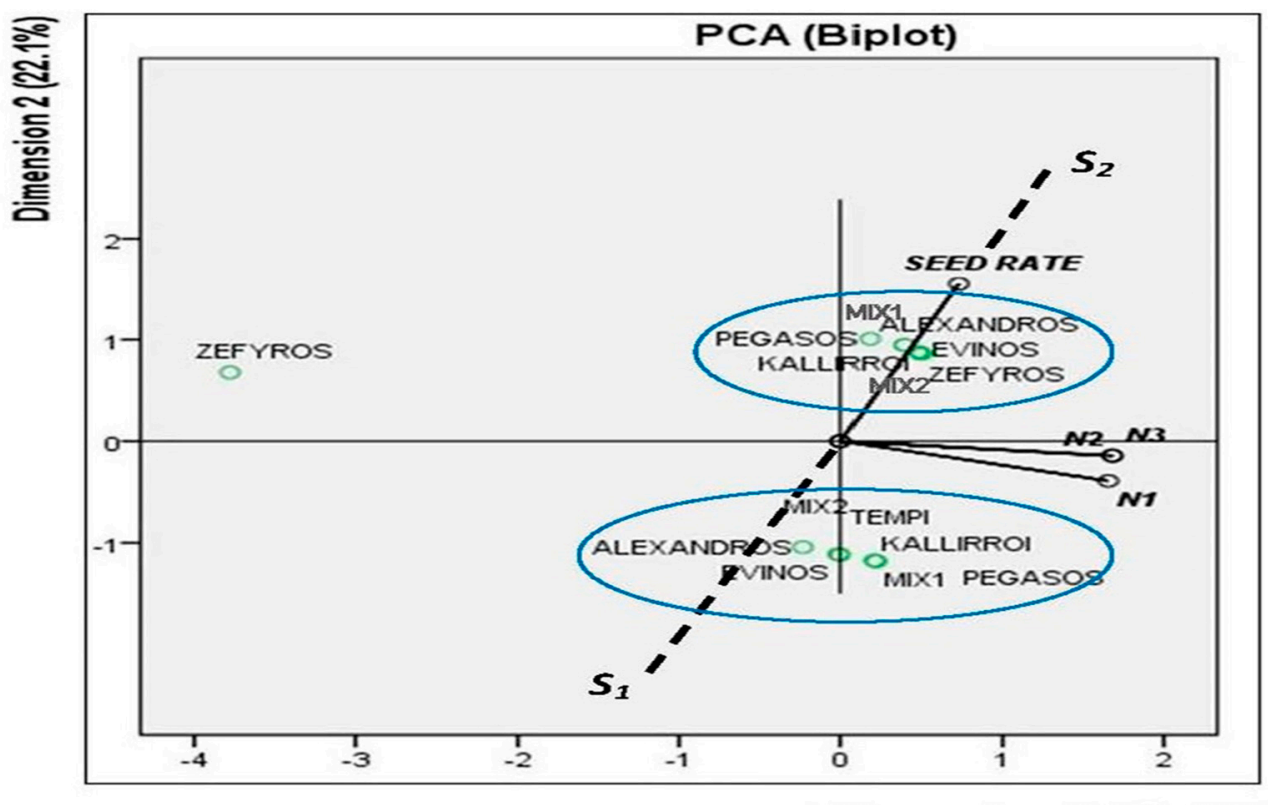

Dimension $1(76.1 \%)$

Figure 4. PCA biplot analyses of residual soil nitrogen two $\left(\mathrm{N}_{1}\right)$, four $\left(\mathrm{N}_{2}\right)$ and six months $\left(\mathrm{N}_{3}\right)$ after incorporation of biomass, for six cultivars and two mixtures of common vetch, at two seed rates $\left(\mathrm{S}_{1}\right.$ : $\left.100 \mathrm{~kg} \mathrm{ha}^{-1} ; \mathrm{S}_{2}: 180 \mathrm{~kg} \mathrm{ha}^{-1}\right)$.

Similarly, four months after the incorporation of common vetch plants, seed rate had no significant impact on residual $\mathrm{N}$ concentration in the upper $40 \mathrm{~cm}$ of the soil profile when averaged across cultivars. Nevertheless, the increment in residual soil nitrogen fluctuated from 17 to $39 \mathrm{~kg} \mathrm{ha}^{-1}$ and from 22 to $45 \mathrm{~kg} \mathrm{ha}^{-1}$ for the different cultivars, at $\mathrm{S}_{1}$ and $S_{2}$, respectively. On the contrary, significant differences among the studied cultivars were detected in both seed rates. In particular, at the low seed rate $\left(\mathrm{S}_{1}\right)$, Mix1 contributed a higher rate of $\mathrm{N}$ accumulation in the soil (viz. $129 \mathrm{~kg} \mathrm{ha}^{-1}$ ), while cv. Zefyros demonstrated a lower rate of $\mathrm{N}$ accumulation (viz. $101 \mathrm{~kg} \mathrm{ha}^{-1}$ ). In the case of the $S_{2}$ seed rate, Mix1 and cv. Zefyros statistically differed from the other cultivars and contributed substantially more $\mathrm{N}$ into the soil (viz. $130 \mathrm{~kg} \mathrm{ha}^{-1}$ and $132 \mathrm{kKg} \mathrm{ha}^{-1}$, respectively), while cv. Alexandros added the smallest amount of nitrogen into the soil (viz. $109 \mathrm{~kg} \mathrm{ha}^{-1}$ ).

Finally, the end of the six-month period after the incorporation led to the recording of a significant difference $(p<0.05)$ between seed rate averaged across cultivars, where, according to Table 4 , the $S_{2}$ seed rate recorded higher values than the $S_{1}$ seed rate $\left(S_{1}\right.$ : $118 \mathrm{~kg} \mathrm{ha}^{-1}$ vs. S2: $\left.127 \mathrm{~kg} \mathrm{ha}^{-1}\right)$. Significant differences $(p<0.05)$ were also observed between cultivars within each seed rate, whilst the residual soil increment was calculated at from 22 to $43 \mathrm{~kg} \mathrm{ha}^{-1}$ at $S_{1}$ and from 28 to $50 \mathrm{~kg} \mathrm{ha}^{-1}$ at $S_{2}$. Once again, at $S_{1}, \mathrm{cv}$. Zefyros contributed the lowest amount of mineralized $\mathrm{N}$ into the soil and Mix1 the highest amount, as their yields were 109 and $130 \mathrm{~kg} \mathrm{ha}^{-1}$, respectively. In the case of $\mathrm{S}_{2}, \mathrm{cv}$. Pegasos contributed the lowest amount of N, estimated at $109 \mathrm{~kg} \mathrm{ha}^{-1}$, while Mix1 and cv. Zefyros contributed the highest amount of $\mathrm{N}$ in soil, at approximately $137 \mathrm{~kg} \mathrm{ha}^{-1}$. It is notable that $\mathrm{cv}$ Pegasos and Evinos presented a differentiation from the rest of the cultivars, since they obtained higher values in the lower seed rate than in the higher seed rate.

Biplot analysis based on principal component analysis (PCA) of residual soil nitrogen $\mathrm{N}_{1}, \mathrm{~N}_{2}$ and $\mathrm{N}_{3}$ at two, four and six months after the incorporation of common vetch plants, respectively, is illustrated in Figure 4 . Variables (viz. seed rate, $\mathrm{N}_{1}, \mathrm{~N}_{2}$ and $\mathrm{N}_{3}$ ) are represented by linear biplot axes pointed in the same directions, whilst cultivars and mixtures are represented by dots [41]. The goodness-of-fit is $98.2 \%$, namely $76.1 \%$ for Dimension 1 and $22.1 \%$ for Dimension 2. Analytically, since the distance between the dots approximates their similarity, we observe that all cultivars grouped into two clusters in relation to seed rate, although no statistical differences was detected in the ANOVA $\left(\mathrm{N}_{1}\right.$ 
and $\mathrm{N}_{2}$ ), as has been shown in Table 4 . This could be interpreted as the ability to use any of the above genotypes for green manuring at a low seed rate and eventually plant population. It is notable that cv Zefyros under $S_{1}$ is differentiated, as it was not grouped in either of two clusters. This could be attributed to genetic or seed rate effects; however, further research is needed to study the cultivar-seed rate interactions.

\subsubsection{Decomposition of Organic Matter}

Decomposition percentage of organic matter derived from Vicia sativa genotypes under study, two $\left(\mathrm{ORG}_{1}\right)$, four $\left(\mathrm{ORG}_{2}\right)$ and six $\left(\mathrm{ORG}_{3}\right)$ months after the placement of plant tissue mesh bags underground, is presented in Table 4, while in Figure 5, the PCA biplot analysis of the corresponding data is illustrated.

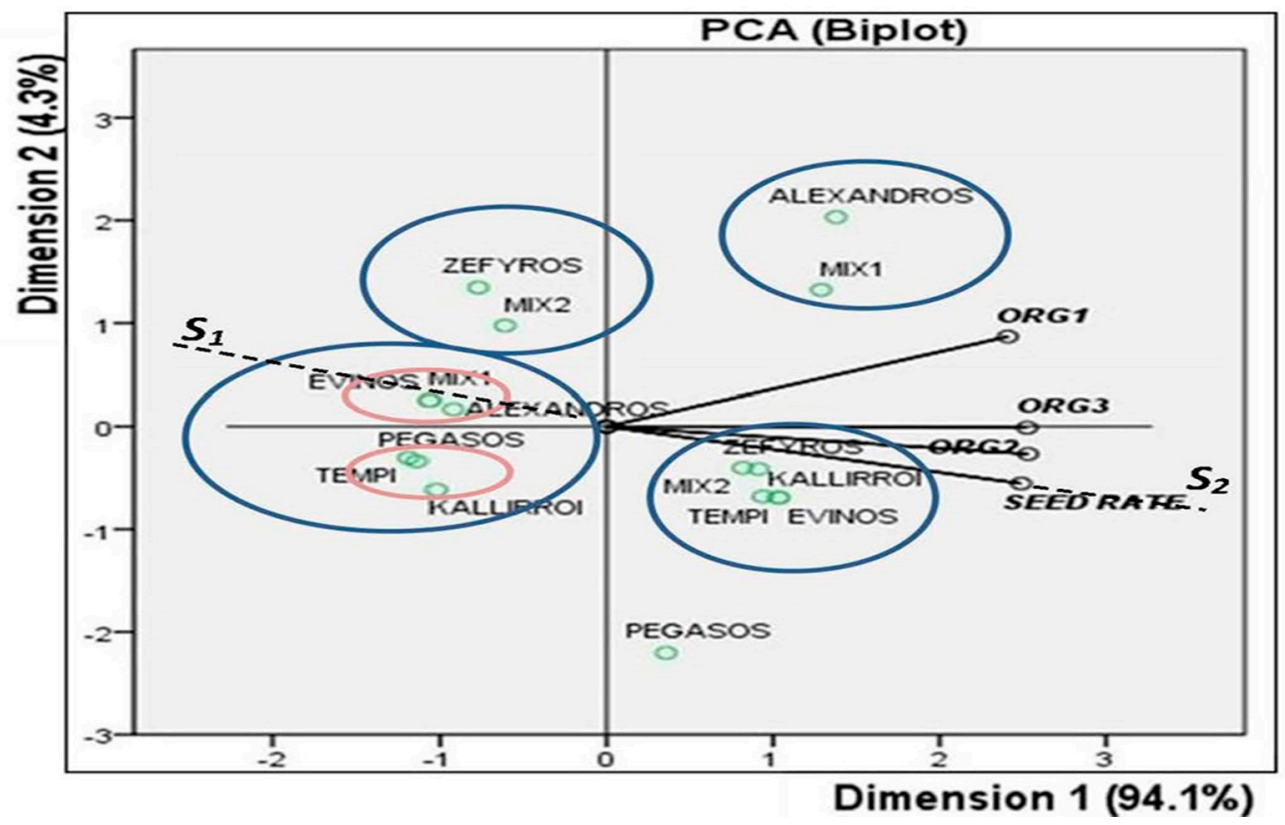

Figure 5. PCA biplot analyses of decomposition percentage of organic matter two $\left(\mathrm{ORG}_{1}\right)$, four $\left(\mathrm{ORG}_{2}\right)$ and six months $\left(\mathrm{ORG}_{3}\right)$ after the incorporation of biomass for six cultivars and two mixtures of common vetch at two seed rates $\left(S_{1}: 100 \mathrm{~kg} \mathrm{ha}^{-1} ; \mathrm{S}_{2}: 180 \mathrm{~kg} \mathrm{ha}^{-1}\right)$.

A significant effect $(p<0.05)$ of seed rate on decomposition of organic matter of common vetch plants was observed in the two-month period. Likewise, significant differences $(p<0.05)$ were detected among cultivars in the same time period, as resulting from Tukey's analysis. Specifically, decomposition rate of green manure of the cultivars Alexandros and Tempi and the mixtures Mix1 and Mix 2 was significantly affected $(p<0.05)$ by seed rate. The higher rate of decomposition was recorded by cv. Tempi at the $S_{1}$ seed rate (viz. $42.8 \%$ ) and by cultivar Alexandros (viz. $42 \%$ ) at the $S_{2}$ seed rate. It is interesting to note that plant tissue of $\mathrm{cv}$. Tempi decomposes to a greater extent at the lower seed rate not only in the two-month period after green manure management, but also in the four- and six-month periods.

Decomposition rate of organic substance had a similar course of development four months after the incorporation of common vetch plants. Seed rate significantly affected the organic matter decomposition of Alexandros, Tempi, Mix1, and Mix2 vetch plants, and significant differences among cultivars were detected at both seed rates. Cultivar Tempi recorded the higher rate of crop residue decomposition at approximately $57.3 \%$ at the $S_{1}$ seed rate, and the mixture Mix2, at approximately $54 \%$, at the $\mathrm{S}_{2}$ seed rate.

The effect of seed rate on the decomposition of organic matter was clearly minor six months after the green manure management, since significant differences were detected only in the cases of the Mix1 and Mix2 mixtures. Otherwise, the obtained data showed a 
slight variation in the recorded values between the four and six-month periods after the incorporation of all vetch plants. Furthermore, at the $S_{1}$ seed rate, no significant differences were detected among the genotypes Alexandros, Pegasos, Evinos, Mix1 and Mix2, while statistically significantly different values were obtained from genotypes Kallirroi and Tempi. Additionally, in the denser plant population, significant differences among cultivars were recorded (Table 4), and decomposition rates fluctuated from $40.41 \%$ to $56.1 \%$.

As depicted by the biplot representation of decomposition of organic matter in Figure 5, there are four distinct clusters of cultivars. The first cluster (upper right) is formed by the cultivar Alexandros and mixture Mix1, with higher values for ORG ${ }_{1}$. In the second cluster (lower right), we find those genotypes that perform better for $\mathrm{ORG}_{2}$. The third group (upper left) consisted of cultivars that display the lowest values at the $S_{1}$ seed rate, six months after the administration of green manure. This last group also coincides with the highest values at the $S_{2}$ seed rate, four months after the green manure. Finally, the last group (lower left) is that formed by cultivars with medium performance with regard to the decomposition of organic matter, especially four months after the incorporation of green manure into the topsoil. Additionally, in this group, we can distinguish two sub-clusters. One sub-cluster is formed by the cultivars Evinos, Mix1 and Alexandros, characterized mainly by their low values for $\mathrm{ORG}_{3}$ at the $\mathrm{S}_{1}$ seed rate, and the other sub-cluster is formed by the cultivars Pegasos, Tempi and Kallirroi, with the lowest values for $\mathrm{ORG}_{1}$ in the denser plantation. The goodness-of-fit is very high at approximately $98.4 \%$.

\section{Discussion}

The assessment framework quantifies the effect of Vicia sativa cultivars used as green manure on residual soil $\mathrm{N}$ and the decomposition of organic matter, aspects that are difficult to measure, and allows us to explore the performance of those cultivars in order to evaluate their introduction into cropping management that leads to environmentally and economically viable prospects.

Concerning plant height, the obtained results show that when the comparison was applied within cultivars, very few differences could be attributed to the seed rate effect; however, significant differences were detected among the genotypes within each seed rate. Such findings are in accordance with previous studies [51-53], indicating that plant height is a characteristic mostly dependent on genotype rather than on cultivation techniques, such as plant density. Further, it is notable that equally high plants were recorded for both seed rates, demonstrated that an increase in seed rate not always leads to an increase in plant height. It is remarkable that the higher the plants were, the higher the obtained LAI values, confirming previous studies [54-56].

According to López-Bellido et al. [57] and Ravasi et al. [58], leaf area index (LAI) is simulated as a function of crop development and the crop responses to seed rate, which is in accordance with the results obtained in the present study, since higher values of LAI were recorded in the higher seed rate $\left(\mathrm{S}_{2}\right)$. In addition, the duration of the period from sowing to flowering and therefore to the fully closed canopy (LAI > 3; light interception > 95\%) is very important for $V$. sativa in order to incure high yield potential in a certain environment [59]. Generally, autumn-sown populations have greater growth duration because they start to grow from the seedling stage [60], which is in agreement with our findings in both plant densities. Moreover, the crop development requires a canopy that enables full light interception and sufficient storage of $\mathrm{N}$ in leaves to maintain a non- $\mathrm{N}$-limited photosynthetic apparatus for converting incoming radiation into new biomass [61]. In full agreement with that, our results reveal that LAI, even at a low seed rate, remained at satisfactory levels and the crop of all genotypes had a closed canopy (LAI > 3) for over 30 days, giving the opportunity to achieve higher productive rates and to minimize losses in photo-synthetically active radiation, demonstrating that all cultivars and mixtures under study are capable of sufficient crop development and are suitable for use as green manure.

Many researchers reported that increasing seed rate resulted in an increased dry matter yield of different legume species including common vetch [62-64], which is consistent with 
our study. In addition, the obtained results demonstrate that despite the slight differences that were recorded in LAI, especially at the higher seed rate, significant differences were observed among Vicia sativa genotypes for biomass (Table 3), reflecting the different yield potential of the monitored genotypes. Vlachostergios et al. [33] reported considerable advantages of cultivar mixtures over their component cultivars for dry matter yield, which were verified by our findings. Analytically, Mix1 and Mix2, along with cv. Alexandros were the highest yielding genotypes for dry biomass.

Regarding the residual soil $\mathrm{N}$ increment, after the incorporation of plants into the topsoil, significant differences within each seed rate were detected between the mixtures and cultivars in almost all cases. It is worth mentioning that the increase in seed rate led to an increment in residual soil $\mathrm{N}$ which was not statistically significantly different $(p<0.05)$ for soil $\mathrm{N}_{1}$ and soil $\mathrm{N}_{2}$ (Table 4). On the contrary, after the time period of six months, the $\mathrm{N}$ concentration in the soil $\left(\mathrm{N}_{3}\right)$ was significantly affected by seed rate in all genotypes and recorded higher values for the $S_{2}$ seed rate. This should be attributed to the additional biomass yield that was produced from the increase in seed rate and hence plant population, since the dominant factor for the mineralization of green manures is the quantity of the biomass of the green manure crops $[65,66]$. However, residual $\mathrm{N}$ concentration recorded high values even in genotypes with a lower dry matter yield (viz. cultivars Evinos and Pegasos), showing that cultivars producing low biomass were not necessarily limited by poor functioning of the soil's $\mathrm{N}_{3}$ fixation processes [67]. In most cases, a higher $\mathrm{N}$ concentration in plant tissue is associated with higher residual soil $\mathrm{N}$ concentration [68]. Our results confirm this, especially in the case of the mixture Mix1, which recorded higher values of soil $\mathrm{N}$ concentration in the time period, studied and had the statistically higher plant nitrogen concentration. Moreover, when comparing the amount of mineralized $\mathrm{N}$ in the soil, it can be seen that sufficient $\mathrm{N}$ soil accumulation was accomplished even at a lower seed rate, and higher levels of $\mathrm{N}$ were released four and six months after the incorporation. These findings can also be attributed to the increased decomposition of organic matter (Table 4) in that time period, since the nitrogen concentration in the soil is strictly related to the soil organic matter, which represents the widest terrestrial reservoir of the element [69]. Additionally, as illustrated in Figure 4, the biplot axes of $\mathrm{N}_{2}$ and $\mathrm{N}_{3}$ coincide, suggesting that the amount of residual $\mathrm{N}$ in the soil remains at the same high levels in the four and sixmonth periods after the green manure management. This comprises an important finding that enables a successful synchronization of subsequent crop's $\mathrm{N}$ demands through the management of the implementation time of green manure. Additionally, the biplot axes of $\mathrm{N}_{2}$ and $\mathrm{N}_{3}$ form an acute angle with the biplot axis of $\mathrm{N}_{1}$, presuming a positive correlation between these variables. Regarding genotypes, there are two distinct clusters. The first cluster (upper left) is formed by the genotypes with the lowest values of residual $\mathrm{N}$, arising mostly from the $S_{1}$ seed rate. The second cluster (lower left) is formed by genotypes that display the highest performance. We pointed out the small distance between genotypes within the same cluster, which indicates the existence of similarities. The cultivar Zefyros is a case apart and displayed away from the two clusters. This specific genotype seems to be strongly seed rate-dependent, since it recorded the lowest values of residual $N$ at the $S_{1}$ seed rate and the highest values at the $S_{2}$ seed rate.

Typically, it is well known that decomposition of organic matter mainly depends on the availability of $\mathrm{N}$ in soil [1,70], as well as the suitable temperature and humidity that benefit microbial activity and thus increase the decomposition rates of the organic material [71-73]. highest values of decomposition rate occurred from September to October $\left(\mathrm{ORG}_{3}\right)$, which was primarily relative to a higher concentration of residual soil $\mathrm{N}_{3}$ (Table 3) and to the favorable environmental conditions (measured data of mild relatively air temperatures and high precipitation) during this period, are in line with Zhang et al.'s [74] findings. In addition, similarly high values of organic matter decomposition were recorded for all genotypes (Table 4$)$ four months $\left(\mathrm{ORG}_{2}\right)$ after the green manure management. These results are confirmed by the PCA biplot representation in Figure 5 in the formation of an acute angle between the biplot axes of $\mathrm{ORG}_{2}$ and $\mathrm{ORG}_{3}$. Additionally, our results show that 
an increment in seed rate does not coincide with an increment in the decomposition of organic matter. Specifically, the cultivar Tempi, followed by the cultivars Kallirroi and Pegasos, recorded higher values at the low $S_{1}$ seed rate and are grouped into a sub-cluster in Figure 5. Hence, these genotypes are not influenced by the seed rate/plant population and can be used in cropping systems as green manure with a low seed rate, a fact that offers options with economic and environmental benefits.

\section{Conclusions}

Common vetch green manure-based systems may provide alternatives to current approaches for sustainable crop production; our work has identified suitable common vetch cultivars and cultivar mixtures with potential for soil fertility improvement via green manure practices in typical Mediterranean environments. Cultivar mixtures seem to be able to compensate for some of the disadvantages relating to cultivars in pure stands and perform better for soil $\mathrm{N}$ concertation, especially under a higher seed rate. However, the use of cultivars mixtures may not be justified without the provision of detailed information about cultivation parameters such as crop growth and development, biomass production and improvement of soil characteristics, among others. In other words, high-performance cultivars can deliver the same, if not better, results in pure stands and can also improve the results of low-performance cultivars when mixed with them. Cultivar mixtures can be a meaningful alternative in situations such as a lack of seed availability or a high cost of high-performance cultivars, for example, but should be carefully designed and include the best 'ingredients' possible in their composition. Additionally, our results suggest that low seed rates might not be recommended, based on biomass production and short-term $\mathrm{N}$ contribution. On the contrary, as most cultivars were found to be seed rate-independent regarding long-term soil $\mathrm{N}$ contribution and the degree of degradation of the organic matter, and residual $\mathrm{N}$ in the soil remains at the same levels in the four- and six-monthperiods after the incorporation of biomass, green manuring at a low seed rate could thus be suggested to improve the profitability and sustainability of green manuring practices, but further research is needed in order to determine the minimum seed rate under which success is compromised.

Author Contributions: Conceptualization, E.T., D.B. (Dimitrios Beslemes) and D.N.V.; methodology, E.T., D.B. (Dimitrios Beslemes), D.B. (Dimitrios Bilalis) and I.T.; validation, E.T. and D.B. (Dimitrios Beslemes); formal analysis, E.T. and D.B. (Dimitrios Beslemes); investigation, E.T., D.B. (Dimitrios Beslemes), I.K. and C.P.; writing—original draft preparation, E.T., D.B. (Dimitrios Beslemes) I.K. and C.P.; writing-review and editing, E.T., D.B. (Dimitrios Bilalis), I.T. and D.N.V.; visualization, E.T., D.B. (Dimitrios Beslemes) and D.N.V.; supervision, D.N.V.; project administration, D.N.V.; funding acquisition, E.T., D.B. (Dimitrios Beslemes) and D.N.V. All authors have read and agreed to the published version of the manuscript.

Funding: This research project was funded under the Action "Research \& Technology Development Innovation projects (AgroETAK)", MIS 453350, in the framework of the Operational Program "Human Resources Development". It was co-funded by the European Social Fund and by National Resources through the National Strategic Reference Framework 2007-2013 (NSRF 2007-2013) coordinated by the Hellenic Agricultural Organization "DEMETER".

Institutional Review Board Statement: Not applicable.

Informed Consent Statement: Not applicable.

Data Availability Statement: The data presented in this study are available on request from the corresponding author. The data are not publicly available due to privacy restrictions.

Acknowledgments: We thank the staff of the Institute of Industrial and Forage Crops for their help during the course of experimentation.

Conflicts of Interest: The authors declare no conflict of interest. 


\section{References}

1. Meena, B.L.; Fagodiya, R.K.; Prajapat, K.; Dotaniya, M.L.; Kaledhonkar, M.J.; Sharma, P.C.; Meena, R.S.; Mitran, T.; Kumar, S. Legume Green Manuring: An Option for Soil Sustainability. In Legumes for Soil Health and Sustainable Management; Meena, R., Das, A., Yadav, G., Lal, R., Eds.; Springer: Singapore, 2018; pp. 387-408.

2. Google. Google Scholar. Available online: http:/ / scholar.google.com (accessed on 2 December 2010).

3. Bilalis, D.; Karkanis, A.; Efthimiadou, A.; Konstantas, A.; Triantafyllidis, V. Effects of irrigation system and green manure on yield and nicotine content of Virginia (flue-cured) Organic tobacco (Nicotiana tabaccum), under Mediterranean conditions. Ind. Crop. Prod. 2009, 29, 388-394. [CrossRef]

4. Dabin, Z.; Pengwei, Y.; Na, Z.; Changwei, Y.; Weidong, C.; Yajun, G. Contribution of green manure legumes to nitrogen dynamics in traditional winter wheat cropping system in the Loess Plateau of China. Eur. J. Agron. 2016, 72, 47-55. [CrossRef]

5. Danga, B.O.; Ouma, J.P.; Wakindiki, I.I.; Bar-Tal, A. Chapter 5 Legume-Wheat Rotation Effects on Residual Soil Moisture, Nitrogen and Wheat Yield in Tropical Regions. Adv. Agron. 2009, 101, 315-349. [CrossRef]

6. Montemurro, F.; Fiore, A.; Campanelli, G.; Tittarelli, F.; Ledda, L.; Canali, S. Organic Fertilization, Green Manure, and Vetch Mulch to Improve Organic Zucchini Yield and Quality. HortScience 2013, 48, 1027-1033. [CrossRef]

7. Biederbeck, V.; Campbell, C.; Rasiah, V.; Zentner, R.; Wen, G. Soil quality attributes as influenced by annual legumes used as green manure. Soil Biol. Biochem. 1998, 30, 1177-1185. [CrossRef]

8. Boparai, B.S.; Singh, Y.; Sharma, B.D. Effect of green manure (Sesbania aculeata) on physical properties of soil and growth of rice-wheat and maize-wheat cropping system. Int. Agrophys 1992, 6, 95-101.

9. Hesterman, O.B.; Griffin, T.S.; Williams, P.T.; Harris, G.H.; Christenson, D. Forage Legume-Small Grain Intercrops: Nitrogen Production and Response of Subsequent Corn. J. Prod. Agric. 1992, 5, 340-348. [CrossRef]

10. Rasmussen, J.; Søegaard, K.; Pirhofer-Walzl, K.; Eriksen, J. N2-fixation and residual N effect of four legume species and four companion grass species. Eur. J. Agron. 2012, 36, 66-74. [CrossRef]

11. Fageria, N.K.; Baligar, V.C.; Bailey, B.A. Role of Cover Crops in Improving Soil and Row Crop Productivity. Commun. Soil Sci. Plant Anal. 2005, 36, 2733-2757. [CrossRef]

12. Beslemes, D.F.; Tigka, E.L.; Efthimiadis, P.; Danalatos, N.G. Biomass Production and N-Use of Fibre Sorghum under Different Cover Cropping Management, Nitrogen Influxes and Soil Types in Central Greece. Exp. Agric. 2013, 50, 109-127. [CrossRef]

13. Tigka, E.; Beslemes, D.; Danalatos, N.; Tzortzios, S. Evaluation of cover-cropping managements on productivity and N-utilization efficiency of kenaf (Hibiscus cannabinus L.), under different nitrogen fertilization rates and soil types. Eur. J. Agron. 2013, 46, 1-9. [CrossRef]

14. Eriksen, J.; Askegaard, M.; Søegaard, K. Residual effect and nitrate leaching in grass-arable rotations: Effect of grassland proportion, sward type and fertilizer history. Soil Use Manag. 2008, 24, 373-382. [CrossRef]

15. Ju, X.-T.; Xing, G.-X.; Chen, X.-P.; Zhang, S.-L.; Zhang, L.-J.; Liu, X.-J.; Cui, Z.-L.; Yin, B.; Christie, P.; Zhu, Z.-L.; et al. Reducing environmental risk by improving $\mathrm{N}$ management in intensive Chinese agricultural systems. Proc. Natl. Acad. Sci. USA 2009, 106, 3041-3046. [CrossRef] [PubMed]

16. Pampana, S.; Masoni, A.; Arduini, I. Response of cool-season grain legumes to waterlogging at flowering. Can. J. Plant Sci. 2016, 96, 597-603. [CrossRef]

17. Haffani, S.; Mezni, M.; Chaibi, W. Agronomic performances of three vetch species growing under different drought levels. Chil. J. Agric. Res. 2014, 74, 263-272. [CrossRef]

18. Martín-Sanz, A.; Palomo, J.L.; Caminero, C. First Report of Bacterial Blight Caused by Pseudomonas syringae pv. syringae on Common Vetch in Spain. Plant Dis. 2009, 93, 1348. [CrossRef]

19. Pampana, S.; Masoni, A.; Mariotti, M.; Ercoli, L.; Arduini, I. Nitrogen Fixation of Grain Legumes Differs in Response to Nitrogen Fertilisation. Exp. Agric. 2018, 54, 66-82. [CrossRef]

20. Mikic, A.; Mihailović, V.; Ćupina, B.; Vasiljevic, S.; Milošević, B.; Katanski, S.; Matić, R.; Radojevic, V.; Kraljević-Balalić, M. Agronomic characteristics related to grain yield and crude protein content in common vetch (Vicia sativa) accessions of diverse geographic origin. N. Z. J. Agric. Res. 2013, 56, 297-308. [CrossRef]

21. Dhima, K.; Lithourgidis, A.; Vasilakoglou, I.; Dordas, C. Competition indices of common vetch and cereal intercrops in two seeding ratio. Field Crop. Res. 2007, 100, 249-256. [CrossRef]

22. Yolcu, H.; Gunes, A.; Dasci, M.; Turan, M.; Serin, Y. The Effects of Solid, Liquid and Combined Cattle Manure Applications on the Yield, Quality and Mineral Contents of Common Vetch and Barley Intercropping Mixture. Ekoloji 2010, 19, 71-81. [CrossRef]

23. Mariotti, M.; Andreuccetti, V.; Arduini, I.; Minieri, S.; Pampana, S. Field bean for forage and grain in short-season rainfed Mediterranean conditions. Ital. J. Agron. 2018, 11, 208-215. [CrossRef]

24. Pichardo-Riego, J.C.; De Postgraduados, C.; Escalante-Estrada, J.A.S.; Díaz-Ruíz, R.; Quevedo-Nolasco, A.; Volke-Haller, V.; Morales-Rosales, E.J.; México, U.A.D.E.D. Water use efficiency and yield for dual purpose in faba bean (vicia faba 1.) cultivars. Rev. Chapingo Ser. Hortic. 2013, XIX, 71-84. [CrossRef]

25. Grela, E.R.; Samolińska, W.; Rybiński, W.; Kiczorowska, B.; Kowalczuk-Vasilev, E.; Matras, J.; Wesołowska, S. Nutritional and Anti-Nutritional Factors in Vicia sativa L. Seeds and the Variability of Phenotypic and Morphological Characteristics of Some Vetch Accessions Cultivated in European Countries. Animals 2020, 11, 44. [CrossRef]

26. Huang, Y.; Gao, X.L.; Nan, Z.B.; Zhang, Z.X. Potential value of the common vetch (Vicia sativaL.) as an animal feedstuff: A review. J. Anim. Physiol. Anim. Nutr. 2017, 101, 807-823. [CrossRef] 
27. Guinet, M.; Nicolardot, B.; Voisin, A.-S. Nitrogen benefits of ten legume pre-crops for wheat assessed by field measurements and modelling. Eur. J. Agron. 2020, 120, 126151. [CrossRef]

28. Rinnofner, T.; Friedel, J.K.; Pietsch, G.; Freyer, B.; de Kruijff, R. Effect of catch crops on N dynamics and following crops in organic farming. Agron. Sustain. Dev. 2008, 28, 551-558. [CrossRef]

29. Vasilakoglou, I.; Dhima, K.; Lithourgidis, A.; Eleftherohorinos, I. Competitive ability of winter cereal-common vetch intercrops against sterile oat. Exp. Agric. 2008, 44, 509-520. [CrossRef]

30. Ercoli, L.; Masoni, A.; Pampana, S.; Arduini, I. Allelopathic effects of rye, brown mustard and hairy vetch on redroot pigwee, common lambsquarter and knotweed. Allelopath. J. 2007, 19, 249-256.

31. Cherr, C.M.; Scholberg, J.M.S.; McSorley, R. Green Manure Approaches to Crop Production: A Synthesis. Agron. J. 2006, 98, 302-319. [CrossRef]

32. Wolfe, M.S. The Current Status and Prospects of Multiline Cultivars and Variety Mixtures for Disease Resistance. Annu. Rev. Phytopathol. 1985, 23, 251-273. [CrossRef]

33. Vlachostergios, D.; Lithourgidis, A.S.; Dordas, C.A.; Baxevanos, D. Advantages of Mixing Common Vetch Cultivars Developed from Conventional Breeding Programs when Grown under Low-Input Farming System. Crop. Sci. 2011, 51, 1274-1281. [CrossRef]

34. Vlachostergios, D.N.; Lithourgidis, A.S.; Korkovelos, A.; Baxevanos, D.; Lazaridou, T.; Khah, A.; Mavromatis, A. Mixing ability of conventionally bred common vetch (Vicia sativa L.) cultivars for grain yield under low-input cultivation. Aust. J. Crop Sci. 2011, 5, 1588-1594.

35. Lal, R.; Delgado, J.A.; Groffman, P.; Millar, N.; Dell, C.; Rotz, A. Management to mitigate and adapt to climate change. J. Soil Water Conserv. 2011, 66, 276-285. [CrossRef]

36. Herridge, D.F.; Peoples, M.B.; Boddey, R.M. Global inputs of biological nitrogen fixation in agricultural systems. Plant and Soil 2008, 311, 1-18. [CrossRef]

37. Rose, T.J.; Kearney, L.J.; Erler, D.V.; Van Zwieten, L. Integration and potential nitrogen contributions of green manure inter-row legumes in coppiced tree cropping systems. Eur. J. Agron. 2019, 103, 47-53. [CrossRef]

38. Beslemes, D.F.; Tigka, E.L.; Efthimiadis, P.; Danalatos, N.G. Maize Biomass Production, N-Use Efficiency and Potential Bioethanol Yield, Under Different Cover Cropping Managements, Nitrogen Influxes and Soil Types, in Mediterranean Climate. J. Agric. Sci. 2013, 5, 189-205. [CrossRef]

39. USDA. Soil Taxonomy: A Basic System of Soil Classification for Making and Interpreting Soil Surveys Agriculture Handbook; United States. Science and Education: Washington, DC, USA, 1975; p. 754.

40. United States Department of Agriculture, Natural Resources Conservation Service. Soil Survey Staff, Keys to Soil Taxonomy, 11th ed.; United States Department of Agriculture, Natural Resources Conservation Service: Washington, DC, USA, 2010.

41. Rueden, C.T.; Schindelin, J.; Hiner, M.C.; Dezonia, B.E.; Walter, A.E.; Arena, E.T.; Eliceiri, K.W. ImageJ2: ImageJ for the next generation of scientific image data. BMC Bioinform. 2017, 18, 529. [CrossRef] [PubMed]

42. Nelson, D.W.; Sommers, L.E. Determination of Total Nitrogen in Plant Material1. Agron. J. 1973, 65, 109-112. [CrossRef]

43. Berg, B.; Müller, M.; Wessén, B. Decomposition of red clover (Trifolium pratense) roots. Soil Biol. Biochem. 1987, 19, 589-593. [CrossRef]

44. Beadle, C.L. Plant Growth Analysis. In Techniques in Bio-Productivity and Photosynthesis and Photosynthesis, 2nd ed.; Coomlos, J.D.O., Long, S.P., Scurlock, J.M.O., Eds.; Pergamon Press: Oxford, UK; New York, NY, USA, 1987; pp. 21-23.

45. Baret, F.; De Solan, B.; Lopez-Lozano, R.; Ma, K.; Weiss, M. GAI estimates of row crops from downward looking digital pho-tos taken perpendicular to rows at $57.5^{\circ}$ zenith angle:Theoretical considerations based on $3 \mathrm{D}$ architecture models and appli-cation to wheat crops. Agric. For. Meteorol. 2010, 150, 1393-1401. [CrossRef]

46. Steel, R.G.D.; Torrie, J.H.; Dickey, D. Principles and Procedures of Statistics: A Biometrical Approach, 3rd ed.; McGraw Hill: New York, NY, USA, 1980; p. 672.

47. Keselman, H.J.; Rogan, J.C. The Tukey multiple comparison test: 1953-1976. Psychol. Bull. 1977, 84, 1050-1056. [CrossRef]

48. Gabriel, K.R. The Biplot graphic display of matrices with application to principal component analysis. Biometrika 1971, 58, $453-467$. [CrossRef]

49. Torres-Salinas, D.; Robinson-García, N.; Jiménez-Contreras, E.; Herrera, F.; López-Cózar, E.D. On the use of biplot analysis for multivariate bibliometric and scientific indicators. J. Am. Soc. Inf. Sci. Technol. 2013, 64, 1468-1479. [CrossRef]

50. Toomsan, B.; Cadisch, G.; Srichantawong, M.; Thongsodsaeng, C.; Giller, K.; Limpinuntana, V. Biological N2 fixation and residual $\mathrm{N}$ benefit of pre-rice leguminous crops and green manures. NJAS-Wagening. J. Life Sci. 2000, 48, 19-29. [CrossRef]

51. Espósito, M.A.; Milanesi, L.A.; Martin, E.A.; Cravero, V.P.; Anido, F.S.L.; Cointry, E.L. Comparison of morphological and molecular data for pea (Pisum sativum) in low and high yielding environments. N. Zealand J. Crop. Hortic. Sci. 2009, 37, 227-233. [CrossRef]

52. Georgieva, N.; Nikolova, I.; Kosev, V. Association study of yield and its components in pea (Pisum sativumL.). Int. J. Pharmacogn. 2015, 2, 536-542. [CrossRef]

53. Saxena, M.C.; Hawtin, G.C.; El-Ibrahim, H. Aspects of Faba Bean Ideotypes for Drier Conditions. In Vicia Faba: Physiology and Breeding; Thompson, R., Ed.; Springer: Dordrecht, The Netherlands, 1981; Volume 4, pp. $210-235$.

54. Falster, D.; Westoby, M. Plant height and evolutionary games. Trends Ecol. Evol. 2003, 18, 337-343. [CrossRef]

55. Iwasa, Y.; Cohen, D.; Leon, J.A. Tree height and crown shape, as results of competitive games. J. Theor. Biol. 1985, 112, 279-297. [CrossRef] 
56. Sakai, S. A model analysis for the adaptive architecture of herbaceous plants. J. Theor. Biol. 1991, 148, 535-544. [CrossRef]

57. López-Bellido, F.; López-Bellido, L. Competition, growth and yield of faba bean (Vicia faba L.). Eur. J. Agron. 2005, 23, 359-378. [CrossRef]

58. Ravasi, R.A.; Paleari, L.; Vesely, F.M.; Movedi, E.; Thoelke, W.; Confalonieri, R. Ideotype definition to adapt legumes to climate change: A case study for field pea in Northern Italy. Agric. For. Meteorol. 2020, 291, 108081. [CrossRef]

59. Bunting, A.H. Time, Phenology and the Yields of Crops*. Weather 1975, 30, 312-325. [CrossRef]

60. Sydorovych, O.; Raczkowski, C.W.; Wossink, A.; Mueller, J.P.; Creamer, N.G.; Hu, S.; Bell, M.; Tu, C. A technique for assessing environmental impact risks of agricultural systems. Renew. Agric. Food Syst. 2009, 24, 234-243. [CrossRef]

61. Salvagiotti, F.; Cassman, K.; Specht, J.; Walters, D.; Weiss, A.; Dobermann, A. Nitrogen uptake, fixation and response to fertilizer N in soybeans: A review. Field Crop. Res. 2008, 108, 1-13. [CrossRef]

62. Açikgöz, E.; Sincik, M.; Öz, M.; Albayrak, S.; Wietgrefe, G.; Turan, Z.; Goksoy, A.; Bilgili, U.; Karasu, A.; Tongel, O.; et al. Forage soybean performance in mediterranean environments. Field Crop. Res. 2007, 103, 239-247. [CrossRef]

63. Atis, I.; Kokten, K.; Hatipoglu, R.; Yilmaz, S.; Atak, M.; Can, E. Plant density and mixture ratio effects on the competition between common vetch and wheat. Aust. J. Crop Sci. 2012, 6, 498-505.

64. Turk, M.A.; Tawaha, A.M.; El-Shatnawi, M.K.J. Response of Lentil (Lens culinaris Medik) to Plant Density, Sowing Date, Phosphorus Fertilization and Ethephon Application in the Absence of Moisture Stress. J. Agron. Crop. Sci. 2003, 189, 1-6. [CrossRef]

65. McCallum, M.H.; Kirkegaard, J.A.; Green, T.W.; Cresswell, H.P.; Davies, S.L.; Angus, J.F.; Peoples, M.B. Improved subsoil macroporosity following perennial pastures. Aust. J. Exp. Agric. 2004, 44, 299-307. [CrossRef]

66. Peoples, M.B.; Brockwell, J.; Herridge, D.F.; Rochester, I.J.; Alves, B.J.R.; Urquiaga, S.; Boddey, R.M.; Dakora, F.D.; Bhattarai, S.; Maskey, S.L.; et al. The contributions of nitrogen-fixing crop legumes to the productivity of agricultural systems. Symbiosis 2009, 48, 1-17. [CrossRef]

67. Büchi, L.; Gebhard, C.-A.; Liebisch, F.; Sinaj, S.; Ramseier, H.; Charles, R. Accumulation of biologically fixed nitrogen by legumes cultivated as cover crops in Switzerland. Plant Soil 2015, 393, 163-175. [CrossRef]

68. Lupwayi, N.; Clayton, G.W.; O’Donovan, J.T.; Harker, K.N.; Turkington, T.K.; Soon, Y.K. Nitrogen release during decomposition of crop residues under conventional and zero tillage. Can. J. Soil Sci. 2006, 86, 11-19. [CrossRef]

69. Triberti, L.; Nastri, A.; Baldoni, G. Long-term effects of crop rotation, manure and mineral fertilisation on carbon sequestration and soil fertility. Eur. J. Agron. 2016, 74, 47-55. [CrossRef]

70. Gil, J.L.; Fick, W.H. Soil Nitrogen Mineralization in Mixtures of Eastern Gamagrass with Alfalfa and Red Clover. Agron. J. 2001, 93, 902-910. [CrossRef]

71. Berg, B.; McClaugherty, C. Plant Litter: Decomposition, Humus Formation, Carbon Sequestration; Springer: Verlag Berlin Heidelberg, Germany, 2020.

72. Osono, T.; Fukasawa, Y.; Takeda, H. Roles of diverse fungi in larch needle-litter decomposition. Mycologia 2003, 95, 820-826. [CrossRef] [PubMed]

73. Reddy, P.P. Sustainable Intensification of Crop Production; Springer Nature Singapore Pte Ltd.: Singapore, 2016.

74. Zhang, D.; Yao, P.; Zhao, N.; Cao, W.; Zhang, S.; Li, Y.; Huang, D.; Zhai, B.; Wang, Z.; Gao, Y. Building up the soil carbon pool via the cultivation of green manure crops in the Loess Plateau of China. Geoderma 2019, 337, 425-433. [CrossRef] 